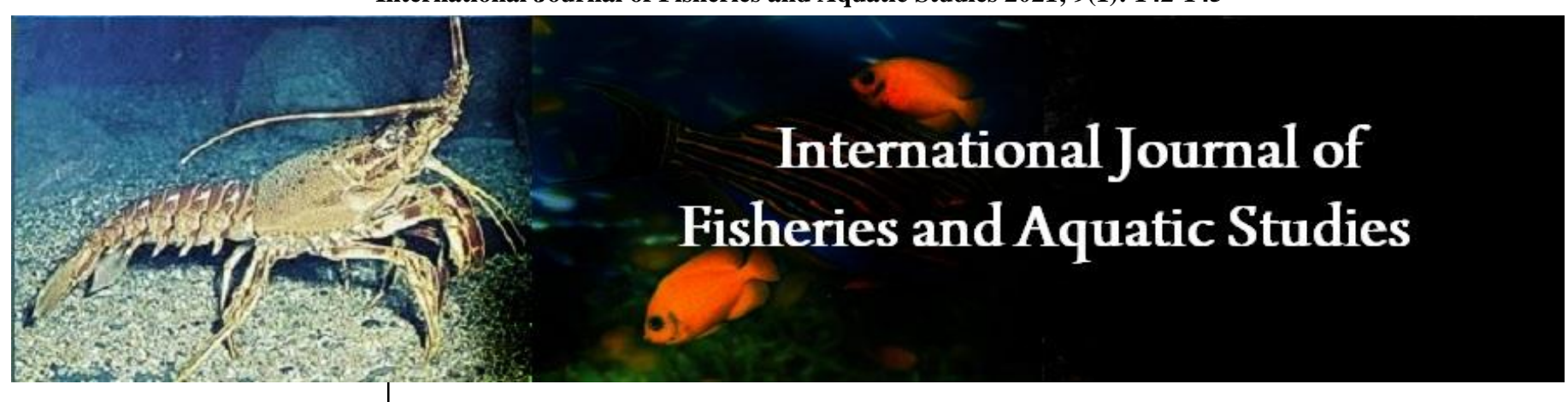

E-ISSN: 2347-5129

P-ISSN: 2394-0506

(ICV-Poland) Impact Value: 5.62

(GIF) Impact Factor: 0.549

IJFAS 2021; 9(1): 142-145

(C) 2021 IJFAS

www.fisheriesjournal.com

Received: 19-11-2020

Accepted: 21-12-2020

Arya Sen

Zoological Survey of India,

M-Block, New Alipore, Kolkata,

West Bengal, India

Chemmencheri Ramakrishnan

Sreeraj

Zoological Survey of India,

Sunderban Regional Centre,

Canning, West Bengal, India

Chelladurai Raghunathan

Zoological Survey of India,

M-Block, New Alipore, Kolkata,

West Bengal, India

Kailash Chandra

Zoological Survey of India,

M-Block, New Alipore, Kolkata,

West Bengal, India
Corresponding Author:

Chemmencheri Ramakrishnan Sreeraj

Zoological Survey of India,

Sunderban Regional Centre,

Canning, West Bengal, India

\section{First report of the fish family Pomacentridae (Damsel fishes) from Sunderban biosphere reserve, India}

\author{
Arya Sen, Chemmencheri Ramakrishnan Sreeraj, Chelladurai \\ Raghunathan and Kailash Chandra
}

DOI: https://doi.org/10.22271/fish.2021.v9.i1b.2396

\begin{abstract}
Sundarban Biosphere Reserve is the largest single strand mangrove forest in the world and houses 350 species of fishes. The present work reports the presence of Indo-Pacific Sergeant fish (Family Pomacentridae) Abudefduf vaigiensis (Quoy \& Gaimard, 1825) from the Sundarban Biosphere Reserve, West Bengal. This is the first report of this family and species from the northern Bay of Bengal region. The species was confirmed through a single specimen collected from Lothian Island in the southern side of Sundarban and the same was compared with a specimen collected from the Arabian Sea.
\end{abstract}

Keywords: Abudefduf, damsel fish, mangrove, sergeant fish

\section{Introduction}

Indian ichthyofauna constitute of 131 species belonging to 67 genera and 28 families of Chondrichthyes and 2415 species belonging to 902 genera, 226 families of Osteichthyes [1]. Till now 24,000 species of finfishes are recorded around the world, of which 2546 species is known to be found in India. Out of the reported species of fishes from India, marine fish diversity itself accounts for nearly $57 \%$ (1440 species) ${ }^{[2]}$. Sundarban Biosphere Reserve contributes to this ichthyofaunal diversity by harboring 350 fish species belonging to 225 genera and 86 families ${ }^{[3]}$. Sundarban acts as natural nursing ground for fishes of various groups, because of its natural topography such as presence of small riverine channels and mangrove swamps etc ${ }^{[4]}$.

Pomacentridae, well known as damsel and anemone fishes are tropical reef fishes having worldwide distribution ${ }^{[5]}$. Damsel fishes belong to the family Pomacentridae and comprises 28 genera and 335 species worldwide ${ }^{[6]}$. Among 335 species, 76 species of pomacentrids are reported from India ${ }^{[7]}$. Pomacentridae specifically prefers tropical reef habitats, either on edge of reef or sheltered lagoons ${ }^{[8]}$. Abudefduf, commonly known as sergeant fishes, is a genus of Pomacentridae, represented by tropical warm water fishes living on coral reefs ${ }^{[9]}$. Abudefduf comprises 19 species worldwide ${ }^{[10]}$, of which six species are reported from India ${ }^{[7]}$. There was no previous record of family Pomacentridae from the mangrove ecosystem of Sunderban Biosphere Reserve. This paper reports the occurrence of Abudefduf vaigiensis (Quoy \& Gaimard, 1825) from the estuarine waters of Sunderban Biosphere Reserve, West Bengal, India.

\section{Materials and Methods}

The fishes were collected using cast net involving the local fishermen in the mangrove habitats of Sunderban during October, 2019. The specimen of Abudefduf was collected from the shallow waters in the south west side of Lothian Island Wildlife Sanctuary $\left(21^{\circ} 42.266^{\prime} \mathrm{N}\right.$, $88^{\circ} 18.703^{\prime} \mathrm{E}$ ) on 12.10.2019 (Fig 1). The collection of fish from Lakshadweep Islands was carried out by hook and line in the coral reef region. The collected fishes were photographed in the field and then fixed in $10 \%$ formalin in seawater solution. Fishes brought to the laboratory were identified using the descriptions in Fish base ${ }^{[10]}$ and later the identified samples were preserved in $70 \%$ ethanol. All length measurements were taken to nearest $0.1 \mathrm{~mm}$ using electronic calipers. 
The specimens are deposited in the National Zoological Collections of the Sunderban Regional Centre of Zoological
Survey of India. The taxonomy followed in the manuscript is based on World Register of Marine Species ${ }^{[11]}$.

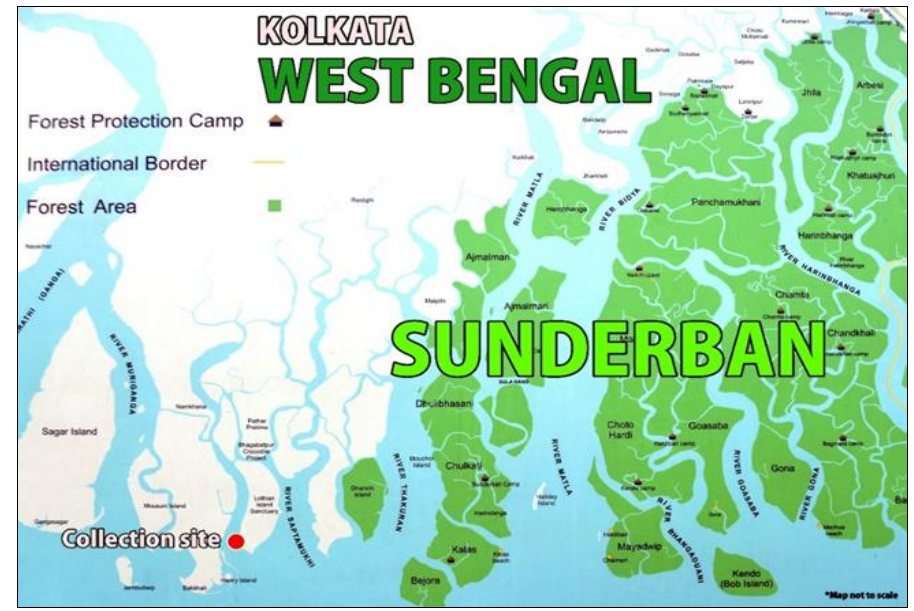

Fig 1: Map of the Sunderban Biosphere Reserve and the collection site.

\section{Results}

The collected specimen was identified as Abudefduf vaigiensis (Quoy \& Gaimard, 1825) and the details are given below:

Material examined: 1 example, Total length $8 \mathrm{~cm}$, Standard length $6 \mathrm{~cm}$, Southern tip of Lothian Island, Sunderban Biosphere Reserve $\left(21^{\circ} 42.266^{\prime} \mathrm{N}, 8^{\circ} 18.703 ' \mathrm{E}\right), 12.10 .2019$, Collected by Arya Sen, Accession Number: ZSI/SbRC/KN 2693; 1 example, Total length $13.6 \mathrm{~cm}$, Standard length $9.9 \mathrm{~cm}$, Androth Island, Lakshadweep, $\left(10^{\circ} 49^{\prime} 3.68^{\prime \prime N}\right.$, 7341'12.86"E), 22.10.2019, Collected by Sreeraj, C.R., Accession Number: ZSI/SbRC/KN 2694; (Deposited in the National Zoological Collections of ZSI-Sunderban Regional Centre).

Taxonomic classification: Class: Actinopterygii (Klein, 1885); Order: Perciformes (Bleeker, 1863); Family: Pomacentridae (Bonaparte, 1832); Genus: Abudefduf (Forsskal, 1775).

\section{Abudefduf vaigiensis (Quoy \& Gaimard, 1825)}

Indo-Pacific sergeant
Conservation Status - Least Concern (IUCN 3.1) (IUCN Red List) ${ }^{[22]}$.

Diagnostic Characters: Dorsal spines 13; dorsal soft rays 13; anal spines 2; anal soft rays 11; Ventral spines 1; Ventral soft rays 5; Pectoral soft rays 18; caudal soft rays 18 . Body rounded in lateral profile and laterally compressed, snout is pointed, one nostril on each side of head. Body color of the dorsal profile is bluish green and silvery to white ventrally. Five broad longitudinal bluish black bands on the body. First band just behind the head and last one at region of caudal peduncle. Last band is narrow comparing to the others. Third to fifth band extends towards dorsal fin. A yellowish coloration is present in between $1^{\text {st }}$ to $4^{\text {th }}$ bar. Caudal fin is forked and without bars, with pointed edge and faint black stripe on margin. Dorsal profile of head straight, covered with scales. Caudal peduncle without groove. Presence of short snout with oblique mouth and lower jaw projectile. Interorbital space little concave. Full body and opercula covered with ctenoid scales. Lateral line is conspicuous. (Fig 2) Detailed measurement of the Bay of Bengal specimen in comparison to same Species collected from Arabian Sea is given in Table 1.
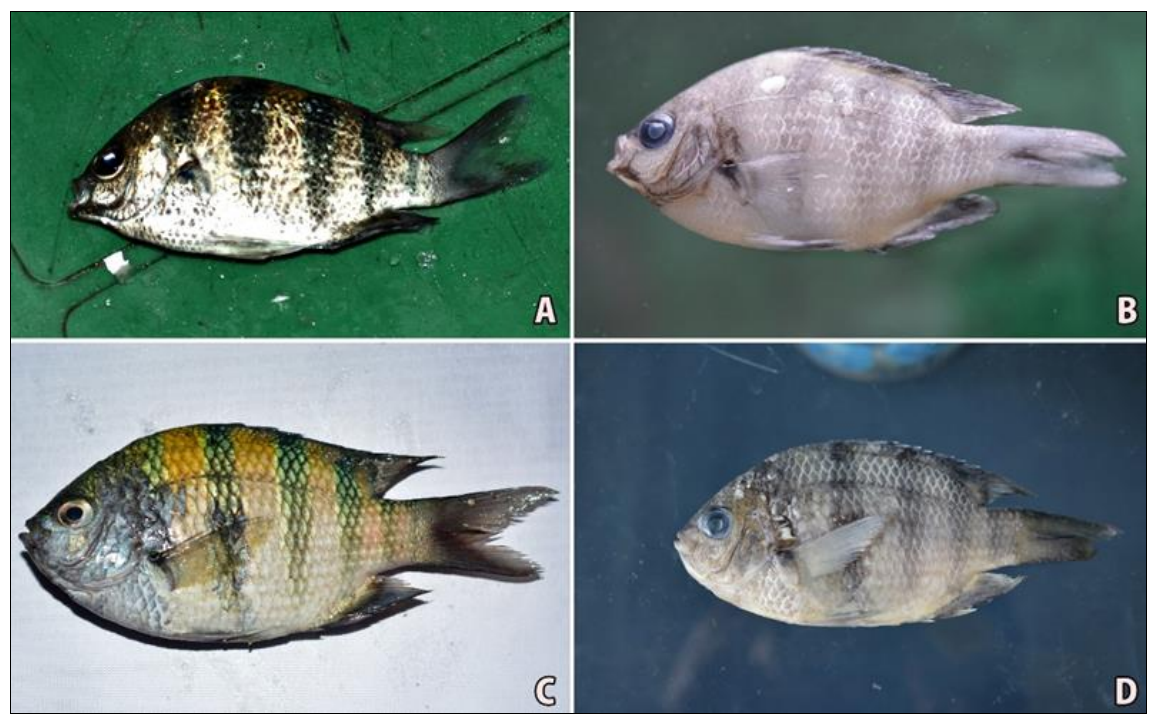

Fig 2: Photographs of A. vaigiensis collected from Sundarban and Lakshadweep Islands. A \& B: Fresh and preserved specimen collected from Sundarban. C \&D: Fresh and preserved specimen collected from Lakshadweep Islands. 
Table 1: Morphometric characteristics of Abudefduf vaigiensis

\begin{tabular}{|c|c|c|c|c|c|c|}
\hline \multirow{2}{*}{ Characters } & \multicolumn{3}{|c|}{ Sunderban } & \multicolumn{3}{|c|}{ Lakshadweep } \\
\hline & Measurements (cm) & In \% with SL & In \% with HL & Measurements (cm) & In \% with SL & In \% with HL \\
\hline Total Length (TL) & 8 & & & 13.6 & & \\
\hline Standard Length (SL) & 6 & & & 9.9 & & \\
\hline Head Length (HL) & 1.8 & 30 & & 3.1 & 31.31 & \\
\hline Eye Diameter & 0.6 & 10 & 33.33 & 0.9 & 9.09 & 29.03 \\
\hline Inter Orbital Length & 0.5 & 8.33 & 27.78 & 1.2 & 12.12 & 38.71 \\
\hline Snout Length & 0.5 & 8.33 & 27.78 & 1 & 10.10 & 32.26 \\
\hline Pectoral Fin Length & 1.51 & 25.17 & & 2.8 & 28.28 & \\
\hline Pelvic Fin length & 1.6 & 26.67 & & 3 & 30.30 & \\
\hline Anal Fin Length & 1.3 & 21.67 & & 2 & 20.20 & \\
\hline Pre-dorsal Length & 2 & 33.33 & & 4.05 & 40.90 & \\
\hline Pre-anal Length & 4.3 & 71.67 & & 7.2 & 72.73 & \\
\hline Pre-pectoral Length & 1.9 & 31.67 & & 3.25 & 32.83 & \\
\hline Pre-pelvic Length & 2.54 & 42.33 & & 4.45 & 44.95 & \\
\hline Body Depth & 2.91 & 48.5 & & 5.02 & 50.71 & \\
\hline Upper Jaw Length & 0.39 & 6.5 & 21.67 & 0.7 & 7.07 & 22.58 \\
\hline Caudal Peduncle Length & 0.7 & 11.67 & & 1.2 & 12.12 & \\
\hline Caudal Peduncle Depth & 0.9 & 15 & & 1.75 & 17.67 & \\
\hline Caudal Fin Length & 1.7 & 28.33 & & 3.7 & 37.37 & \\
\hline
\end{tabular}

\section{Distribution}

India: Konkan region (Karnataka, Goa, Maharastra), Coromandel region (Tamil Nadu), West Bengal and Andaman and Nicobar Islands.

Elsewhere: From Red Sea and eastern Africa to the Line and Tuamoto islands, north to southern Japan, and south to Australia and New Zealand.

Remarks: Found in marine reef areas, mainly coral or stony region, with strong substratum and crevices, within 1 to $15-$ meter water depth of tropical waters in Indo-Pacific region. Records of this species in the Indian Ocean were mostly from the coral reef regions. This is the first record of this family and the species from Sunderbans. A. vaigiensis is often confused with and misidentified as a closely related Atlantic species; A. saxatilis (Linnaeus, 1758). Structural similarity between these two species leads to a misinterpretation in the identification process ${ }^{[12]}$. From India also A. saxatilis is reported from many parts such as Andaman and Nicobar Islands, Lakshadweep Islands and Tamilnadu (Gulf of Mannar) by various authors (Table 2) ${ }^{[13,14,15]}$. A. saxatilis is strictly an Atlantic species and commonly spotted at Caribbean reefs and Western Africa to Angola ${ }^{[16]}$. Whereas A. vaigiensis is Indo-Pacific in origin ${ }^{[9]}$. As there are no evidence of A. saxatilis for being an invasive species in India, it is reiterated that the reports of $A$. saxatilis from India are erroneous identifications and are to be considered as $A$. vaigiensis.

Table 2: List of Abudefduf species reported from India and its distribution (*A. vaigiensis wrongly identified as A. saxatilis, ANI - Andaman and Nicobar Islands, GoM - Gulf of Mannar, LD - Lakshadweep, GA - Goa, GJ - Gujarat, AP - Andhra Pradesh, P - Present)

\begin{tabular}{|c|c|c|c|c|c|c|c|c|c|}
\hline SI No & Species & ANI & GJ & TN & LD & GA & KA & AP & References \\
\hline 1 & Abudefduf bengalensis & $\mathrm{P}$ & $\mathrm{P}$ & $\mathrm{P}$ & $\mathrm{P}$ & & & & $13,14,17,18,24$ \\
\hline 2 & Abudefduf manikfani & & & & $\mathrm{P}$ & & & & 24 \\
\hline 3 & Abudefduf septemfasciatus & $\mathrm{P}$ & & & $\mathrm{P}$ & & & & 14,24 \\
\hline 4 & Abudefduf sexfasciatus & $\mathrm{P}$ & $\mathrm{P}$ & & $\mathrm{P}$ & & & $\mathrm{P}$ & $14,15,18,19$ \\
\hline 5 & Abudefduf sordidus & $\mathrm{P}$ & $\mathrm{P}$ & & $\mathrm{P}$ & $\mathrm{P}$ & $\mathrm{P}$ & & $14,17,20,21,18,24$ \\
\hline 6 & Abudefduf vaigiensis & $\mathrm{P}$ & & $\mathrm{P}$ & $\mathrm{P}$ & $\mathrm{P}$ & $\mathrm{P}$ & & $14,10,25$ \\
\hline 7 & Abudefduf saxatilis* & $\mathrm{P}$ & & $\mathrm{P}$ & $\mathrm{P}$ & & & & $13,14,24$ \\
\hline
\end{tabular}

\section{Discussion and Conclusion}

Species of Abudefduf specifically prefers marine reef habitat. The name translates as "the father of the reef" (Arabic, Abu = Father). They are the first line of defense for the reefs against other species, hence they are commonly called 'sergeant fish'. In India, Abudefduf species are reported from various reef areas along the coastal region as well as the Islands (Table 2). From the distribution data of this genus in India, it is clear that Abudefduf sp. prefers only marine reef regions as its habitat. Even in West Bengal, five species of pomacentrids namely Abudefduf bengalensis (Bloch, 1787); Abudefduf vaigiensis (Quoy \& Gaimard, 1825); Amphiprion akallopisos Bleeker, 1853; Amphiprion clarkii (Bennett, 1830) and Dascyllus trimaculatus (Rüppell, 1829) reported from the coastal area, namely Digha coast. However, in this case $A$. vaigiensis is being reported from Gangetic Delta region, i.e.
Sunderban Biosphere reserve for the first time. Occurrence of this genus and species from Mangrove ecosystem is quite exceptional as there was no previous evidence of this genus being reported from Mangroves. It is contradicting to the natural habitat preference of A. vaigiensis, as Sunderban Biosphere Reserve is an estuarine region with brackish water and muddy bottoms (due to high rate of sediment deposition in deltaic region). Any kind of reef (specifically rocky bottom) are not reported from this region ${ }^{[4]}$. Further investigation on the substratum in the region is very much essential for making any concluding statement on the habitat preference of this species.

There are 350 fish species reported from Sunderban Biosphere Reserve ${ }^{[3]}$. This new report adds a whole family and a species to the Sunderban's ichthyofaunal diversity. Further detailed investigation on the fish diversity of this vast 
mangrove habitat might certainly help in recording more species from the region.

\section{Acknowledgements}

The work was carried out as part of the project titled "Long Term monitoring of faunal diversity of Sunderban Biosphere", funded by The Department of Forests, West Bengal Government, India. Authors are also thankful to the Director, Field Director and Joint Director of Sunderban Biosphere Reserve and the Divisional Forest Officer, South Parganas and other forest officials for the support and cooperation in carrying out the work in Sunderban. First author would like to thank Dr. D. Suresh Chand, Scientist-D and Project Co-Ordinator and Dr. R. Aengals, Officer-InCharge, Sunderban Regional Centre of Zoological Survey of India for the constant support and guidance in the work. The support of the fellow researchers during the field work is also duly acknowledged.

\section{References}

1. Environmental Information System. Centre for ecological sciences Indian institute of science. India. http://wgbis.ces.iisc.ernet.in/energy/water/paper/fishdiver sity/diversity 1.html' 2019.

2. Nair RJ, Dinesh KS. Overview of the Fish Diversity of Indian Waters. CMFRI Training Manual Series No.15/2018. 2018, 35-66.

3. Mishra SS, Gopi KC. Fish diversity of Indian Sundarban. In: Fauna of Sundarban Biosphere Reserve. Zoological Survey of India, Kolkata. 2017, 107-127.

4. Chandra G, Sagar R. Fisheries in Sundarbans: problems and prospects 2003. Available at SSRN 2084014.

5. Martínez-Torres M, Reyes-Bonilla H, Melo FJFR, Sánchez-Alcántara I, González-Cuellar OT, MoralesPortillo CD. Range extension of the blue and yellow damselfish Chromis limbaughi (Pomacentridae) to the northern Gulf of California, Mexico. Marine Biodiversity Records 2014;7:E43. doi:10.1017/S1755267214000281

6. Nelson JS, Grande TC, Wilson MV. Fishes of the World. John Wiley \& Sons 2016, 1067.

7. Rajan PT, Sreeraj CR. Fish fauna of Andaman and Nicobar Islands: A review. In: Ecology and Conservation of Tropical Marine Faunal Communities. Springer, Berlin, Heidelberg 2013, 231-243.

8. Sale PF. The science we need to develop for more effective management. Coral Reef Fishes Dynamics and Diversity in a Complex Ecosystem (Sale, PF ed.) 2002, 361-376.

9. Allen GR. Damselfishes of the world. Mergus Publishers, Germany 1991, 271.

10. Froese R, Pauly D. (Eds) Fish Base. World Wide Web electronic publication. www.fishbase.org 2020.

11. WoRMS Editorial Board. World Register of Marine Species. http://www.marinespecies.org at VLIZ 2019.

12. Tsadok R, Rubin-Blum M, Shemesh E, Tchernov D. On the occurrence and identification of Abudefduf saxatilis (Linnaeus, 1758) in the easternmost Mediterranean Sea. Aquatic invasions 2015;10(1):101-105.

13. Kumar JSY, Geetha S, Sornaraj R. Diversity and distribution of reef fishes in Gulf of Mannar islands, India. In: Ecology and Conservation of Tropical Marine Faunal Communities. Springer, Berlin, Heidelberg 2013, 297-310.

14. Rajan PT, Sreeraj CR, Immanuel T. Fishes of Andaman and Nicobar Islands: a checklist. Journal of Andaman Science Association 2013;18(1):47-87.

15. Murty VS. Marine ornamental fish resources of Lakshadweep. CMFRI special publication 2002;72:1134.

16. Randall JE. Caribbean reef fishes. Third Edition - revised and enlarged. 3rd Ed. T.F.H. Publications, Inc. Ltd: Hong Kong 1996, 368.

17. Parmar H, Barad D, Parasharya D. Reef dependent ichthyofauna of the Gulf of Kachchh, Gujarat, Western India. International Journal of Fisheries and Aquatic Studies 2015;2(6):33-37.

18. Kizhakudan JK, Fofandi KN. Marine ornamental fishes of Gujarat. Sustainable Fisheries Development: Focus on Gujarat 2003, 180-185.

19. Padmavathi D. Finfish atlas of egree. egree Foundation, An initiative of GoI-UNDP-GEF-GoAP(EGREE) Project, Kakinada, Andhra Pradesh, India 2017, 790.

20. Thomas S, Sreeram MP, Kakati VS, Manisseri MK, George RM. Coral fish diversity in Netrani waters off Murudeshwar Karnataka, south India. Indian Journal of Fisheries 2011;58(1):45-51.

21. Tsering L, Pawar HB, Sreepada RA, Sanaye SV, Suryavanshi U. Ichthyofaunal diversity and ecology of intertidal rock pools of Goa, west coast of India. Fishing Chimes 2012;32(8):56-59.

22. The IUCN Red List of Threatened Species. Version 2019-2. http://www.iucnredlist.org. 2019.

23. Vattakaven T, George RM, Balasubramanian D, RéjouMéchain M, Muthusankar G, Ramesh BR et al. India Biodiversity Portal: An integrated, interactive and participatory biodiversity informatics platform. Biodiversity Data Journal (4). 2016; 2019. https://doi.org/10.3897/BDJ.4.e10279

24. Jones S, Kumaran M. Fishes of the Laccadive Archipelago. The Nature Conservation and Aquatic Sciences Service, Kerala, India 1980, 760.

25. Ajith KTT, Vinoth R, Prakash S, Balasubramanian T. Reef fishes of the Lakshadweep Archipelago, Centre of Advanced study in Marine Biology, Faculty of Marine Sciences, Annamalai University, Tamilnadu, India 2012, 180. 